\title{
ANALISIS KEMAMPUAN BERPIKIR KREATIF MATEMATIS SISWA KELAS VIII PADA MATERI SISTEM PERSAMAAN LINEAR DUA VARIABEL (SPLDV)
}

\author{
Evi Siti Sopiah ${ }^{1}$, Adang Effendi², Yoni Sunaryo ${ }^{3}$ \\ 1,2,3 Program Studi Pendidikan Matematika, Universitas Galuh, Jl. R. E. Martadinata No.150, Ciamis, Indonesia \\ Email : evi.sitisopiah97@gmail.com
}

\begin{abstract}
The ability to think creatively is one of the important factors of learning objectives because providing knowledge solely to students will not help them much in everyday life. Therefore, learning should be designed by the development of students' attitudes and abilities to overcome problems in the future. creatively. The subjects of this study were students of class VIII MTs Cinyasag, Panawangan District with a total of 6 students consisting of students with low, medium and high math abilities, each of which consisting of two students. The technique of collecting data is by means of subjective essay test and interview. The data analysis technique used in this study was data triangulation. Based on the results of the study, it revealed that: 1) based on the indicator of fluency, students who have moderate and low abilities, are able to remember and apply formulas and are able to perform calculations correctly, also, they are able to give conclusions orally and written well even though they used their own language; 2) based on the indicator of flexibility, students who have low mathematical creative thinking skills have not been able to apply formulas and do calculations correctly; meanwhile, students who have moderate and high mathematical creative thinking skills tend to be able to complete answers in various ways; 3) based on the indicators of authenticity, students who have low, medium, and high mathematical creative thinking skills, tend to be less ability in working on and solving questions with their own answers or think on their own; 4) based on the elaboration indicator, almost all of students are able to complete answers, although there are some students who are less ability to complete answers in detail.
\end{abstract}

Keywords: Students' Mathematical Creative Thinking Ability, SPLDV

\begin{abstract}
ABSTRAK
Kemampuan berpikir kreatif merupakan salah satu faktor penting dalam tujuan pembelajaran karena hanya dengan memberi pengetahuan saja tidak akan banyak menolong siswa dalam kehidupan sehari-hari. Oleh karena itu, pembelajaran disertai pengembangan sikap dan kemampuan siswa dalam menghadapi persoalan- persoalan di masa mendatang secara kreatif sangat penting. Subjek penelitian ini adalah siswa kelas VIII MTs Cinyasag Kecamatan Panawangan dengan jumlah siswa sebanyak 6 orang yang terdiri dari siswa yang berkemampuan matematika rendah sedang, dan tinggi; masing-masing terdiri dari dua orang siswa. Teknik pengambilan data dilakukan dengan tes uraian dan wawancara. Sedangkan teknik analisis data menggunakan triangulasi data. Hasil penelitian menunjukkan bahwa: 1) Berdasarkan indikator kelancaran, siswa yang memiliki kemampuan sedang dan rendah mampu mengingat dan menerapkan rumus serta mampu melakukan perhitungan dengan tepat, serta mampu memberikan kesimpulan secara lisan dan tulisan dengan baik meskipun dengan menggunakan bahasa sendiri; 2)Berdasarkan indikator keluwesan, siswa yang memiliki kemampuan berpikir kreatif matematis rendah belum mampu menerapkan rumus dan melakukan perhitungan dengan tepat; edangkan, siswa yang memiliki kemampuan berpikir kreatif matematis sedang dan tinggi cenderung mampu menyelesaikan jawaban dengan berbagai macam cara; 3) Pada indikator keaslian siswa yang memiliki kemampuan berpikir kreatif matematis rendah, sedang, dan tinggi, mereka cenderung kurang mampu mengerjakan dan menyelesaikan soal dengan jawaban sendiri atau pemikiran sendiri; 4) Pada indikator elaborasi hampir semua siswa mampu menyelesaikan jawaban, meskipun terdapat beberapa siswa yang kurang mampu menyelesaikan jawaban secara terperinci.
\end{abstract}

Kata Kunci: Kemampuan Berfikir Kreatif Matematis Siswa, SPLDV

Cara sitasi: Sopiah, E, S., Effendi, A., \& Sunaryo, Y. (2020). Analisis Kemampuan Berpikir Kreatif Matematis Siswa Kelas VIII pada Materi Sistem Persamaan Linear Dua Variabel (SPLDV). J-KIP (Jurnal Keguruan dan IImu Pendidikan) , 1 (2), 1-10. 


\section{PENDAHULUAN}

Pendidikan merupakan hal penting dalam rangka meningkatkan kualitas Sumber Daya Manusia baik dari segi spiritual, intelegensi, maupun skill untuk menunjang kehidupannya. Hal tersebut tercantum dalam Undang-undang Sistem Nomor 20 Tahun 2003 tentang sistem Pendidikan Nasional, Tujuan pendidikan nasional adalah untuk berkembangnya potensi peserta didik agar menjadi manusia yang beriman dan bertakwa kepada Tuhan Yang Maha Esa, berakhlak mulia, berilmu, cakap, mandiri dan menjadi warga Negara yang demokratis serta bertanggung jawab. Pendidikan merupakan upaya mencerdaskan kehidupan bangsa, salah satunya dengan melakukan proses pembelajaran matematika. Matematika merupakan mata pelajaran yang diajarkan pada setiap jenis dan jenjang pendidikan."Melalui pembelajaran matematika, siswa juga dituntut untuk memiliki kemampuan-kemampuan yang disebut kemampuan matematis.Kemampuan matematis merupakan kemampuan untuk menghadapi permasalahan, baik dalam matematika maupun kehidupan nyata" (Ramdhani, 2016).

Berdasarkan National Council of Teachers of Mathematics [NCTM] (2000), disebutkan bahwa terdapat lima kemampuan dasar matematika yang merupakan standar kemampuan matematika meliputi belajar untuk berkomunikasi (mathematical communication), belajar untuk bernalar (mathematical reasoning), belajar untuk memecahkan masalah (mathematical problem solving), belajar untuk mengaitkan ide (mathematical connecting), dan belajar untuk mempresentasikan ide-ide (mathematical representation). Pengembangan terbaru, yaitu kurikulum 2013 mengupayakan peningkatan mutu pendidikan untuk menghasilkan lulusan yang kreatif dan mampu menghadapi kehidupan pada masa yang akan datang.Pengembangan kurikulum ini masih mengupayakan agar siswa memiliki kemampuan berpikir kreatif yang dapat dikembangkan melalui pendidikan untuk menghadapi tantangan-tantangan kehidupan di masa yang akan datang karena masalah yang dihadapi akan lebih kompleks dan rumit.

Salah satu mata pelajaran yang memiliki peranan penting dalam kemajuan dunia pendidikan adalah matematika. Matematika adalah suatu alat untuk mengembangkan cara berpikir. Matematika tidak hanya diajarkan untuk mengetahui dan memahami apa yang terkandung dalam matematika tersebut, tetapi matematika juga diajarkan untuk membangun pola pikir dan nalar siswa untuk memecahkan suatu persoalan atau masalah dengan berfikir kreatif, kritis, logis, dan tepat. Matematika merupakan kunci utama dari pengetahuan-pengetahuan lain yang dipelajari di sekolah. Tujuan utama dari pendidikan matematika pada jenjang pendidikan dasar dan menengah adalah memahami konsep matematik, penalaran pada pola dan sifat, memecahkan masalah yang meliputi kemampuan memahami masalah, kreatif, mengomunikasikan gagasan dengan simbol, tabel, diagram, atau media lain dan memiliki sikap menghargai (Aisyah, 2007)

Dengan demikian, matematika menjadi mata pelajaran yang sangat penting dalam pendidikan dan wajib dipelajari pada setiap jenjang pendidikan. Pada dasarnya belajar matematika merupakan belajar konsep, sedangkan konsep-konsep dasar matematika merupakan kesatuan yang bulat dan utuh.Walaupun pengajaran matematika dilakukan dengan memperhatikan urutan konsep dan dimulai dari hal yang sederhana, tetapi sampai saat ini matematika masih dianggap sebagai pelajaran yang sulit. Akibatnya banyak siswa yang bersikap acuh dalam proses belajar mengajar matematika. Anggapan inilah yang dapat melemahkan semangat belajar siswa sehingga akan menjadi malas dan tidak suka dengan pelajaran matematika. Pembelajaran yang aktif akanmemicu kemampuan berpikir kreatif siswa. Kemampuan berpikir kreatif perlu dikembangkan oleh peserta didik karena memiliki banyak manfaat, diantaranya yaitu berpikir kreatif dapat mewujudkan dirinya, karena perwujudan diri merupakan kebutuhan pokok dalam hidup manusia.

Menurut Risnanosanti (2010) yang menyatakan bahwa kemampuan berpikir kreatif matematis siswa masih kurang dalam menyelesaiakan soal-soal kebaruan karena tidak terbiasa menyelesaikan permasalahan dengan cara sendiri. Hal ini juga terjadi pada peserta didik MTs Cinyasag Kecamatan Panawangan. Hasil wawancara menunjukkan bahwa kemampuan berpikir tingkat tinggi matematis 
pada peserta didik MTs Cinyasag Kecamatan Panawangan seperti berpikir kreatif masih kurang. Semiawan (Sumarmo, 2014) mengumukakan kreativitas adalah kemampuan menyusun ide baru dan menerapkannya dalam pemecahan masalah, dan kemampuan mengidentifikasikan asosiasi antara dua ide yang kurang jelas.

Peran aktif dari siswa sangat penting dalam rangka pembentukan generasi yang kreatif, yang mampu menghasilkan sesuatu untuk kepentingan dirinya dan orang lain. Kemampuan berpikir kreatif merupakan suatu kemampuan berpikir original dan refleksif serta menghasilkan sesuatu yang kompleks termasuk mensintesiskan gagasan-gagasan, memunculkan ide-ide baru, menentukan efektivitas suatu gagasan, mampu membuat keputusan dan memunculkan generalisasi. Menurut Siswono (2008), kemampuan berpikir kreatif merupakan salah satu faktor penting dari tujuan pembelajaran karena memberi pengetahuan semata-mata kepada siswa tidak akan banyak menolongnya dalam kehidupan sehari-hari, sehingga dalam pembelajaran sebaiknya dapat mengembangkan sikap dan kemampuan peserta siswa yang dapat membantu untuk menghadapi persoalan-persoalan di masa mendatang secara kreatif.

Berdasarkan hasil wawancara yang diakukan oleh peneliti terhadap guru mata pelajaran matematika kelas VIII disalah satu MTs di Kecamatan Panawangan Kabupaten Ciamis menyatakan bahwa kemampuan berpikir kreatif matematis siswa berdasarkan hasil ulangan harian dan ulangan akhir semester bahwa siswa yang memiliki kemampuan berpikir kreatif matematis bervariasi yaitu berkemampuan berpikir kreatif tinggi, sedang dan rendah. Penelitian ini diharapkan dapat memberikan gambaran yang lebih spesifik dengan mengelompokan objek penelitian berdasarkan kemampuan berpikir kreatif matematis.

Tujuan penelitian adalah untuk mengetahui gambaran kemampuan berpikir kreatif matematis siswa dalam menyelesaikan soal-soal Sistem Persamaan Linear Dua Variabel (SPLDV). Dalam penelitian ini, peneliti membatasi masalah hanya pada kemampuan berpikir kreatif matematis siswa pada indikator kelancaran, keluwesan, keaslian dan elaborasi kelas VIII dalam menyelesaikan soal Sistem Persamaan Linear Dua Variabel (SPLDV) berdasarkan indikator kemampuan berpikir kreatif.

\section{METODE PENELITIAN}

Penelitian ini dilaksanakan di MTs Cinyasag Panawangan pada siswa kelas VIII. Penelitian ini dilaksanakan pada semester genap sekitar bulan April-Mei Tahun 2020. Adapun subyek penelitian dalam penelitian ini adalah siswa kelas VIII MTs Cinyasag Kecamatan Panawangan dengan jumlah siswa sebanyak 6 orang yang terdiri dari siswa yang berkemampuan matematika rendah sedang, dan tinggi masing-masing terdiri dari dua orang siswa. Subyek diperoleh berdasarkan saran dari guru mata pelajaran Matematika kelas VIII MTs Cinyasag Kecamatan Panawangan.

Strategi penelitian yang digunakan adalah pendekatan kualitatif dengan metode studi kasus. Studi kasus yang digunakan dalam penelitian ini adalah dengan menggunakan soal tes kemampuan berpikir kreatif matematis dengan cara mengumpulkan data-data sesuai dengan yang sebenarnya kemudian data tersebut disusun, diolah, dan dianalisis untuk dapat memberikan gambaran kemampuan berpikir kreatif matematis siswa pada pokok bahasan Sistem Persamaan Linear Dua Variavel (SPLDV) berdasarkan empat indikator kemampuan berpikir kreatif matematis yaitu Kelancaran (fluency), Keluwesan (flexibility), Keaslian (originality), dan Elaborasi (elaboration). Peneliti menggunakan prosedur pengumpulan data yang lain berupa tes, wawancara dan dokumentasi untuk memperkuat hasil data penelitian. Teknik analisis data yang digunakan dalam penelitian ini adalah triangulasi data. Triangulasi data yaitu teknik pengedekan data dari berbagai sumber dengan berbagai cara dan waktu. 


\section{HASIL DAN PEMBAHASAN}

Tes kemampuan berfikir kreatif matematis siswa dilaksanakan terhadap 6 orang siswa yang memiliki kemampuan berfikir kreatif matematis tinggi, sedang dan rendah. Berikut penulis sajikan data mengenai subjek penelitian pada Tabel 1.

Tabel 1. Subjek Penelitian

\begin{tabular}{clcc}
\hline No & Nama Siswa & P/L & Jenis Kemampuan \\
\hline 1 & MFAG & $\mathrm{L}$ & Rendah \\
2 & SSA & $\mathrm{P}$ & Rendah \\
3 & ADTG & $\mathrm{P}$ & Sedang \\
4 & RS & $\mathrm{P}$ & Sedang \\
5 & GSA & $\mathrm{L}$ & Tinggi \\
6 & SAG & $\mathrm{P}$ & Tinggi \\
\hline
\end{tabular}

Berdasarkan hasil tes soal nomor 1, MFAG mampu mengerjakan soal dengan jawaban yang benar, tetapi kurang mampu menyelesaikan dengan tepat.Terlihat bahwa dalam menyelesaika soal MFAG kurang mampu menyelesaikan soal dengan baik. Kemudian pada subjek 2 yakni SSA, SSA kurang mampu mengingat atau menerapkan rumus dengan tepat.Terlihat bahwa dalam menyelesaika soal SSA tidak mampu menyelesaikan soal dengan baik dan tepat. Selanjutnya peserta didik yang memiliki kemampuan sedang, ADTG mampu mengingat dan menerapkan rumus, namun terdapat pengerjaan yang kurang tepat, ADTG kurang menuliskan pemisalan pada harga buku dan harga pensil. Tetapi, hasil dari jawabannya sudah tepat dengan jumlah yang seharusnya. Selanjutnya adalah RS, RS mampu mengingat dan menerapkan rumus dan mampu menghitung secara tepat. Terlihat bahwa dalam menyelesaikan soal, RS mampu menyelesaikan soal secara tepat dengan 2 kemungkinan. RS memberikan kesimpulan dan perhitungan yang tepat. Untuik siswa berkemampuan tinggi yakni GSA dan SAG, GSA mampu mengingat dan menerapkan rumus dan mampu menghitung secara tepat dengan 2 kemungkinan yang benar. Terlihat bahwa dalam menyelesaikan soal, GSA mampu menyelesaikan soal secara tepat dalam penerapan rumusnya. GSA memberikan kesimpulan dan perhitungan tepat. Dan SAG mampu mengingat dan menerapkan rumus dan mampu menghitung secara tepat dengan 2 kemungkinan.Terlihat bahwa dalam menyelesaikan soal, SAG mampu menyelesaikan soal dengan tepat dalam penerapan rumusnya. SAG memberikan kesimpulan dan perhitungan yang tepat.

Berdasarkan hasil analisis, siswa yang memiliki kemampuan berpikir kreatif matematis rendah, MFAG dan SSA. Pada soal nomor 1 dengan kategori soal mudah, MFAG mampu mengingat rumus tetapi tidak mampu menerapkan rumus dengan tepat, sedangkan SSA tidak mampu mengingat dan menerapkan rumus dengan tepat. MFAG dan SSA tidak mampu menyelesaikan soal dengan baik. Sedangkan, siswa yang memiliki kemampuan berpikir kreatif matematis sedang, ADTG dan RS mampu mengingat dan menerapkan rumus dari SPLDV, meskipun terdapat pengerjaan yang kurang tepat, tetapi ADTG dan RS mampu memberikan jawaban dengan benar dan dapat dimengerti meskipun terdapat kata yang kurang tepat. Pada siswa yang memiliki kemampuan berpikir kreatif matematis tinggi, GSA dan SAG mampu mengingat dan menerapkan rumus dengan tepat dan memberikan kesimpulan diakhir jawaban dengan sangat baik. Kemampuan berpikir kreatif siswa begitu diperlukan oleh siswa. Pada perkembangannya kemampuan berpikir kreatif, kritis, pemecahan masalah, dan penalaran matematika dapat mewujudkan kemampuan berpikir tingkat tinggi (Kumar, 2008). Dengan demikian, dapat disimpulkan bahwa siswa yang memiliki kemampuan sedang dan rendah, mampu mengingat dan menerapkan rumus serta mampu melakukan perhitungan dengan tepat. Siswa dengan kemampuan sedang dan rendah mampu memberikan kesimpulan secara lisan dan tulisan dengan baik meskipun dengan menggunakan bahasa sendiri.

Selanjutnya adalah analisis terhadap hasil pengerjaan soal nomor 2, MFAG belum mampu menyelesaikan masalah dengan menggunakan bermacam- macam cara dalam menyelesaikan masalah yang terkait dengan materi pada pembelajaran matematika dengan sempurna. Terlihat bahwa dalam menyelesaikan soal, MFAG belum mamu menyelesaikan soal secara sempurna. 
Disamping itu, masih adanya pengoperasian yang salah dalam melakukan proses eliminasi. Selanjutnya adalah SSA, SSA belum mampu menyelesaikan masalah dengan menggunakan bermacam- macam cara dalam menyelesaikan masalah yang terkait dengan materi pada pembelajaran matematika dengan sempurna. Terlihat bahwa dalam menyelesaikan soal, SSA sama sekali tidak memahami proses penyelesaian dari soal yang diberikan baik proses eliminasi maupun subtitusi. Disamping itu, SSA masih belum menerapkan penyelesaian soal secara matematis. Kemudian untuk siswa berkemampuan matematika sedang yakni ADTG dan RS, ADTG mampu menyelesaikan masalah dengan menggunakan bermacam- macam caradalam menyelesaikan masalah yang terkait dengan materi pada pembelajaran matematika dengan cukup sempurna. Terlihat bahwa dalam menyelesaikan soal, ADTG mampu memahami proses penyelesaian dari soal yang diberikan baik proses eliminasi maupun subtitusi. Disamping itu, ADTG mampu menerapkan penyelesaian soal secara matematis, walaupun belum secaralengkap. Dan RS mampu menyelesaikan masalah dengan menggunakan bermacam- macam cara dalam menyelesaikan masalah yang terkait dengan materi pada pembelajaran matematika dengan cukup sempurna. Terlihat bahwa dalam menyelesaikan soal, RS mampu memahami proses penyelesaian dari soal yang diberikan baik proses eliminasi maupun subtitusi. Akan tetapi penyelesaian soal yang diberikan kepada RS belum diselesaikan secara matematis dengan sempurna. Untuk selanjutnya bagi siswa berkemampuan matematika tinggi yakni GSA dan SAG. GSA mampu menyelesaikan masalah dengan menggunakan bermacam- macam cara dalam menyelesaikan masalah yang terkait dengan materi pada pembelajaran matematika dengan sempurna. Terlihat bahwa dalam menyelesaikan soal, GSA memahami alur penyelesaian soal dengan sangat baik. Kemudian penyelesaian soal yang dilakukan terperinci dengan baik dan sistematis. Dan SAG mampu menyelesaikan masalah dengan menggunakan bermacam- macam cara dalam menyelesaikan masalah yang terkait dengan materi pada pembelajaran matematika dengan sangat sempurna. Terlihat bahwa dalam menyelesaikan soal, SAG sangat memahami alur penyelesaian soal dengan sangat baik. Kemudian penyelesaian soal yang dilakukan terperinci dengan sangat baik dan sistematis.

Berdasarkan hail analisis yang dilakukan, siswa yang memiliki kemampuan berpikir kreatif matematis rendah, MFAG dan SSA. MFAG mampu menerapkan rumus tetapi kurang mampu melakukan perhitungan dengan tepat. Sedangkan SSA, tidak mampu menerapkan dan melakukan perhitungan dengan tepat. Berdasarkan wawancara, hal ini dikarenakan SSA tidak mampu mengingat rumus yang hendak digunakan sehingga ia merasa kesulitan dalam melakukan perhitungan dan menyelesaikan permasalahan dengan tepat. Siswa yang memiliki kemampuan berpikir kreatif matematis sedang dan tinggi, cenderung mampu menerapkan rumus dan melakukan perhitungan dengan tepat. Krulik, Rudnick \& Milou (2003) menyatakan bahwa memecahkan suatu permasalahan merupakan suatu proses, dimana setiap individu menggunakan keahlian dan pemahaman sebelumnya yang dikembangkan dan diaplikasikan ke dalam situasi yang tidak biasa. Dengan demikian, dapat disimpulkan bahwa siswa yang memiliki kemampuan berpikir kreatif matematis rendah belum mampu menerapkan rumus dan melakukan perhitungan dengan tepat. Sedangkan, siswa yang memiliki kemampuan berpikir kreatif matematis sedang dan tinggi cenderung mampu menyelesaikan jawaban dengan berbagai macam cara. Setiap siswa mampu menyelesaikan permasalahan matematika menggunakan keahlian mereka sendiri berdasarkan pengalaman ataupun pengetahuan yang telah didapatkan sebelumnya. Pada kemampuan berpikir kreatif ini perhatian siswa perlu difokuskan yaitu dengan meminta siswa untuk mengingat rumus/konsep yang telah dipelajari sesuai dengan permasalahan dan melakukan tanya jawab dengan memberikan pertanyaan arahan/petunjuk dan juga meminta siswa untuk memeriksa kembali jawabannya dengan teliti.

Analisis selanjutnya adalah soal nomor 3 . Berdasarkan hasil tes pada soal nomor 3 , subjek 1 yakni MFAG belum mampu menyelesaikan masalah dengan menemukan penyelesaian dari sebuah masalah terkait dengan materi pada pembelajaran matematika dengan menggunakan gagasan atau cara sendiri.Terlihat bahwa dalam menyelesaikan soal, MFAG belum mamu menyelesaikan soal 
secara sempurna. Disamping itu, MFAG masih menggunakan cara umum dalam menyelesaikan soal yang diberikan. Penyelesaian soal yang diberikan pun tidak mampu disempurnakan dengan jawaban lengkap yang semestinya. Kemudian untuk SSA, SSA belum mampu menyelesaikan masalah dengan menemukan penyelesaian dari sebuah masalah terkait dengan materi pada pembelajaran matematika dengan menggunakan gagasan atau cara sendiri. Terlihat bahwa dalam menyelesaikan soal, Jangankan untuk mencari penyelesaian dengan cara sendiri, menggunakan cara umum saja (eliminasi dan subtitusi) masih ada kekeliruan. Disamping itu, SSA masih belum menerapkan penyelesaian soal secara matematis. Untuk Siswa berkemampuan matematika sedang yakni subjek ADTG dan RS. ADTG belum mampu menyelesaikan masalah dengan menemukan penyelesaian dari sebuah masalah terkait dengan materi pada pembelajaran matematika dengan menggunakan gagasan atau cara sendiri. Hal tersebut dikarenakan penyelesaian soal masih dilakukan dengan menggunakan cara umum yakni eliminasi dan subtitusi. Akan tetapi, secara keseluruhan ADTG mampu memahami proses penyelesaian dari soal yang diberikan baik proses eliminasi maupun subtitusi.

Disamping itu, ADTG belum dapat mengerjakan soal sesuai dengan penyelesaian soal matematika yang sempurna. Kemudian RS, RS belum mampu menyelesaikan masalah dengan menemukan penyelesaian dari sebuah masalah terkait dengan materi pada pembelajaran matematika dengan menggunakan gagasan atau cara sendiri. Hal tersebut dikarenakan penyelesaian soal masih dilakukan dengan menggunakan cara umum yakni eliminasi dan subtitusi. Terlihat bahwa dalam menyelesaikan soal, RS mampu memahami proses penyelesaian dari soal yang diberikan baik proses eliminasi maupun subtitusi. Akan tetapi penyelesaian soal yang diberikan kepada RS belum diselesaikan secara matematis dengan sempurna dan bukan dengan cara sendiri melainkan masih dengan menggunakan penyelesaian baku yakni eliminasi dan subtitusi. Dan untuk siswa berkemampuan matematika tinggi yakni GSA dan SAG, pada dasarnya telah mampu menyelesaikan masalah dengan sangat baik. Seperti misalnya GSA belum mampu menyelesaikan masalah dengan menemukan penyelesaian dari sebuah masalah terkait dengan materi pada pembelajaran matematika dengan menggunakan gagasan atau cara sendiri. Hal tersebut dikarenakan penyelesaian soal masih dilakukan dengan menggunakan cara umum yakni eliminasi dan subtisusi Terlihat bahwa dalam menyelesaikan soal, GSA sangat memahami alur penyelesaian soal dengan sangat baik dan menggunakan eliminasi dan subtitusi. Kemudian penyelesaian soal yang dilakukan terperinci dengan baik dan sistematis. Dan SAG mampu menyelesaikan masalah denganmenemukan penyelesaian dari sebuah masalah terkait dengan materi pada pembelajaran matematika dengan menggunakan gagasan atau cara sendiri. Terlihat bahwa dalam menyelesaikan soal, SAG sangat memahami alur penyelesaian soal dengan sangat baik. Kemudian penyelesaian soal yang dilakukan terperinci dengan sangat baik dan sistematis. Disamping itu cara yang digunakan oleh SAG dalam menyelesaikan soal berbeda dari yang lain, dimana SAG tidak melakukan eliminasi akan tetapi langsung dengan menggunakan 2 tahapan subtitusi.

Berdasarkan hasil analisis yang dilakukan, siswa yang memiliki kemampuan berpikir kreatif matematis rendah, sedang, dan tinggi, mereka cenderung kurang mampu mengerjakan dan menyelesaikan soal dengan jawaban sendiri atau pemikiran sendiri. Dalam indikator ini siswa cenderug menyelelsaikan soal dengan menggunakan rumus pada umumnya. Akan tetapi pada siswa yang memiliki kemampuan berpikir kreatif tinggi, SAG berusaha untuk menyelesaikan dengan tepat, terdapat langkah yang menuju ke jawaban yang diharapkan, SAG mencoba menyelesaikan soal tanpa melakukan eliminasi. SAG meneyelesaikan soal yang diberikan dengan cara melakukan subtitusi. Langkah awal yang dilakukan SAG adalah merubah salah satu persamaan, sehingga setelah persamaan dirubah ke dalam bentuk yang berbeda, SAG dapat langsung mensubtitusikan persamaan ke persamaan lainnya. Jadi proses penyelesaian yang dilakukan SAG adalah subtitusi. Proses penyelesaian soal yang diberikan, dilakukan oleh SAG dengan sangat terperinci dan sistematis dan tentunya matematis. Akan tetapi mengingat hanya 1 siswa yang mampu menyelesaikan soal dengan 
jalan yang berbeda sesuai dengan pemikirannya sendiri, dapat disimpulkan bahwa hampir semua siswa belum mampu menyelesaikan soal dengan cara pemikiran sendiri.

Kemampuan berpikir kreatif berhubungan erat dengan pemecahan masalah matematika. Pada umumnya masalah matematika yang diberikan kepada siswa berbentuk soal cerita. Soal cerita merupakan cerita sederhana yang mengacu pada pengalaman kontekstual yang diakhiri dengan pertanyaan yang memiliki satu-satunya jawaban benar. Jika kita mengasumsikan bahwa kreativitas adalah tentang menghasilkan solusi baru, akan sulit bagi kita untuk berbicara tentang solusi kreatif untuk soal cerita tersebut. Sehingga penting bagi guru untuk menyajikan soal cerita yang mampu mendorong kemampuan berpikir kreatif siswa. Sifat terbuka dari soal cerita yang diajukan diharapkan mampu mendorong kreativitas siswa sehingga siswa akan dihadapkan pada masalah dengan berbagai jawaban yang benar, melihat masalah dengan cara yang berbeda dan menemukan solusi terbaik untuk masalah ini. Santrock (2011) mengatakan bahwa: "kreativitas ialah kemampuan berpikir tentang sesuatu dengan cara baru dan tak biasa dalam menghasilkan solusi yang unik atas suatu masalah. Jadi, satu diantara cara yang dapat digunakan untuk mengukur dan mengembangkan kemampuan berpikir kreatif adalah pemecahan masalah". Kemudian Sabandar (2008), menjelaskan bahwaberpikir kreatif sesungguhnya adalah suatu kemampuan berpikir yang berawal dari adanya kepekaan terhadap situasi yang sedang dihadapi, bahwa situasi itu terlihat atau teridentifikasi adanya masalah yang ingin harus diselesaikan. Selanjutnya ada unsur originalitas gagasan yang muncul dalam benak seseorang terkait dengan apa yang teridentifikasi.

Kemudian untuk soal tes nomor 4 tentang kemampuan berpikir kreatif matematis yang memuat indikator yaitu elaboratif yaitu siswa dapat mengembangkan, memperkaya atau menguraikan suatu materi dalam pembelajaran matematika secara terperinci. Subjek MFAG belum mampu menyelesaikan masalah dengan mengembangkan, memperkaya atau menguraikan suatu materi dalam pembelajaran matematika secara terperinci.Terlihat bahwa dalam menyelesaikan soal, MFAG belum mamu menyelesaikan soal secara sempurna. Penyelesaian soal yang diberikan pun tidak mampu disempurnakan dengan jawaban lengkap yang semestinya. Kelengkapan penyelesaian soal dalam bentuk matematis blm diterapkan dengan baik. Dan untuk SSA belum mampu menyelesaikan masalah dengan mengembangkan, memperkaya atau menguraikan suatu materi dalam pembelajaran matematika secara terperinci. Terlihat bahwa dalam menyelesaikan soal, SSA belum memahami alur penyelesaian soal dengan menggunakan eliminasi dan subtitusi. Disamping itu, SSA masih belum menerapkan penyelesaian soal secara matematis. Selain MFAG dan SSA, ADTG belum mampu menyelesaikan masalah denganmengembangkan, memperkaya atau menguraikan suatu materi dalam pembelajaran matematika secara terperinci. Hal tersebut dikarenakan penyelesaian soal dilakukan dengan tidak sempurna dan tidak sesuai dengan proses eliminasi yang seharusnya. Akan tetapi, secara keseluruhan ADTG memahami dasar proses penyelesaian dari soal yang diberikan baik proses eliminasi maupun subtitusi. Disamping itu, ADTG masih kurang teliti dalam membaca soal yang diberikan, sehingga kesalahan dalam pengerjaan masih terjadi. Kemudian RS belum mampu menyelesaikan masalah denganmengembangkan, memperkaya atau menguraikan suatu materi dalam pembelajaran matematika secara terperinci. Hal tersebut dikarenakan penyelesaian soal belum dilakukan secara matematis dengan sempurna. Terlihat bahwa dalam menyelesaikan soal, RS mampu memahami proses penyelesaian dari soal yang diberikan baik proses eliminasi maupun subtitusi. Dan untuk siswa berkemampuan tinggi, GSA belum mampu menyelesaikan masalah dengan mengembangkan, memperkaya atau menguraikan suatu materi dalam pembelajaran matematika secara terperinci. Hal tersebut dikarenakan penyelesaian soal dilakukan dengan sistematis dan terperinci, GSA sangat memahami alur penyelesaian soal dengan sangat baik dan menggunakan eliminasi dan subtitusi. Dan SAG mampu menyelesaikan masalah dengan mengembangkan, memperkaya atau menguraikan suatu materi dalam pembelajaran matematika secara terperinci. Terlihat bahwa dalam menyelesaikan soal, SAG sangat memahami alur penyelesaian soal dengan 
sangat baik, sistematis dan terperinci. Kemudian penyelesaian soal yang dilakukan terperinci dengan sangat baik dan sistematis.

Berdasarkan hasil analisis yang dilakukan, siswa yang memiliki kemampuan berpikir kreatif matematis rendah, MFAG dan SSA belum mampu menyelesaikan (jawaban) dengan baik, hal tersebut dikarenakan MFAG dan SSA kurang mampu menguraikan jawaban secara terperinci. Berdasarkan hasil wawancara, MFAG kurang mampu memahami isi soal, sedangkan SA kurang mampu memahami langkah-langkah pengerjaan dalam menyelesaikan permasalahan. Siswa yang memiliki kemampuan berpikir kreatif matematis sedang yakni ADTG masih kurang teliti dalam membaca soal. Sehingga ada kesalahan salam pengerjaan soal. Kemudian untuk siswa yang memiliki kemampuan berfikir kreatif matematis sedang lainnya yakni RS mampu menyelesaikan (jawaban) dengan baik, terurai dan secara terperinci.

Kemudian siswa yang memiliki kemampuan berfikir kreatif matematis tinggi yakni GSA dan SAG, sangat mampu menyelesaikan (jawaban) dengan sangat baik, terurai dan sangat terperinci. Dengan demikian, dapat disimpulkan bahwa hampir semua siswa mampu menyelesaikan jawaban, meskipun terdapat beberapa siswa yang kurang mampu menyelesaikan jawaban secara terperinci dengan baik.

Munandar (Mulyana \& Sabandar, 2005) mengatakan bahwa ciri-ciri kemampuan yang berpikir kreatif yang berhungan dengan kognitif memiliki ciri-ciri mampu mengembangkan atau memperkaya gagasan orang lain dan menambahkan atau memperici suatu gagasan sehingga meningkatkan kualitas gagasan tersebut.

\section{KESIMPULAN}

Berdasarkan hasil penelitian dan pembahasan, dapat diambil simpulan bahwa pada indikator kelancaran siswa yang memiliki kemampuan sedang dan rendah, mampu mengingat dan menerapkan rumus serta mampu melakukan perhitungan dengan tepat. Siswa dengan kemampuan sedang dan rendah mampu memberikan kesimpulan secara lisan dan tulisan dengan baik meskipun dengan menggunakan bahasa sendiri. Kemudian pada indikator keluwesan siswa yang memiliki kemampuan berpikir kreatif matematis rendah belum mampu menerapkan rumus dan melakukan perhitungan dengan tepat. Sedangkan, siswa yang memiliki kemampuan berpikir kreatif matematis sedang dan tinggi cenderung mampu menyelesaikan jawaban dengan berbagai macam cara. Selanjutnya pada indikator keaslian siswa yang memiliki kemampuan berpikir kreatif matematis rendah, sedang, dan tinggi, mereka cenderung kurang mampu mengerjakan dan menyelesaikan soal dengan jawaban sendiri atau pemikiran sendiri. Dan pada indikator elaborasi hampir semua siswa mampu menyelesaikan jawaban, meskipun terdapat beberapa siswa yang kurang mampu menyelesaikan jawaban secara terperinci.

\section{REKOMENDASI}

Penelitian ini meneliti kelima indikator kemampuan berpikir kreatif yakni kelancaran, keluwesan, keaslian, elaborasi dan keaslian dikarenakan karakteristik dari materinya sesuai, untuk penelitian pada materi lainnya maka sebaiknya memperhatikan kesesuaian antara indicator dan karakteristik materi.

\section{UCAPAN TERIMAKASIH}

Peneliti mengucapkan terimakasih kepada kepala MTs Cinyasag Panawangan dan siswa kelas VIII MTs Cinyasag Kecamatan Panawangan tahun akademik 2019/2020 karena telah mendukung terhadap pelaksanaan penelitian ini. Selain itu, ucapan terimakasih juga ditujukan kepada pembimbing dan menejemen program studi pendidikan matematika yang telah memberikan arahan dan motivasi kepada peneliti untuk menyelesaikan penelitian ini. 


\section{DAFTAR PUSTAKA}

Aisyah, N.L. (2007). Panduan Apresiasi Puisi dan Pembelajarannya. Bandung: Rumput Merah.

Krulik, S., Rudnik, J., \& Milou, E. (2003). Teaching Mathematics In Middle Schools. A practical guide. Boston: Pearson Education Inc.

Kumar, C. R. (2008). Research Methodology. New Delhi: APH Publishing Corporation.

Mulyana, T \& Sabandar, J. (2005). Upaya Meningkatkan Kemampuan Berpikir Kreatif Matematik Siswa SMA Jurusan IPA melalui Pembelajaran dengan Pendekatan Deduktif-Induktif. Makalah. Disampaikan pada Seminar Nasional. Bandung, 20 Agustus 2005. Diselenggarakan oleh Jurusan Pendidikan Matematika FPMIPA UPI.

Ramdhani, T. (2016) Hubungan Komunikasi Terapeutik Perawat dengan Kepuasan Pasien Rawat Inap Di Puskesmas 1 Dayeuhluhur Tahun 2016. Bachelor Thesis, Universitas Muhammadiyah Purwokerto.

Risnanosanti. (2010). Kemampuan Berpikir Kreatif Matematis dan Self Efficacy terhadap Matematika Siswa Sekolah Menengah Atas (SMA) dalam Pembelajaran Inkuiri. UPI: Disertasi.

Sabandar, J. (2008). "Thinking Classroom" dalam Pembelajaran Matematika di Sekolah. Prosiding 20 Desember 2008.

Santrock, J. W. (2011). Perkembangan Anak Edisi 7 Jilid 2. (Terjemahan: Sarah Genis B) Jakarta: Erlangga.

Siswono, T, Y, E. (2008). Identifikasi Proses Berpikir Kreatif Siswa dalam Pengajuan Masalah (Problem Posing) Matematika Berpadu dengan Model Wallas dan Creative Problem Solving (CPS) Di SMP NEGERI 4 dan SMP NEGERI 26 Surabaya. Buletin Pendidikan Matematika, 6 (2).

Sumarmo, U. (2014). Berpikir dan Disposisi Matematik Serta Pembelajarannya. Kumpulan Makalah. FMIPA UPI. Bandung. Diterbitkan. 
